\title{
ОПТИМІЗАЦІЯ НАВЧАЛЬНОГО ПРОЦЕСУ НА ЗАОЧНОМУ ЦИКЛІ ІНТЕРНАТУРИ
}

\author{
ДВНЗ “Івано-Франківський національниймедичний університет”

\section{OPTIMIZATION OF THE EDUCATIONAL PROCESS AT THE CORRESPONDENCE CYCLE OF INTERNSHIP}

I. С. Головчак

\author{
I. S. Holovchak
}

\author{
SHEI "Ivano-Frankivsk National Medical University"
}

\begin{abstract}
Завданням очної інтернатури є максимальне інформаційне насичення навчання, підвищення якості теоретичної підготовки з їі корекцією на всіх етапах, контроль ефективності практичного та професійного зростання, формування навичок клінічного мислення та диференційної діагностики.

Заочне навчання проходить на клінічних базах стажування. ЗПСМ є інтегрованою дисципліною і включає елементи 23 спеціальностей. Тому основним завданням заочного циклу є формування практичного кругозору, ознайомлення 3 усім широким спектром нозологій, необхідним для проведення диференційної діагностики. Основним документом, який регламентує професійну підготовку лікаря-інтерна, $є$ індивідуальний навчальний план. Його заповнення на очному циклі та базах стажування проводиться інтернами самостійно під контролем керівників інтернатури та відповідального викладача профільної кафедри. У звітних формах, які завіряються підписом керівника інтернатури та керівника закладу охорони здоров'я регіону, зазначається кількість проконсультованих та пролікованих пацієнтів, проведених маніпуляцій згідно з переліком практичних навиків, передбачених навчальним планом. На заочному циклі навчання інтерни зобов'язані опрацювати перелік обов'язкової та додаткової для вивчення літератури, написати низку рефератів. Такий підхід передбачає індивідуалізацію постійного професійного зростання теоретичної та практичної підготовки молодого фахівця, його відповідність сучасним запитам практичної охорони здоров'я.
\end{abstract}

The objective is to maximize the full-time internship information saturation education, improving the quality of its theoretical background correction at all stages, monitoring the effectiveness of practical and professional growth, the skills of thinking and clinical differential diagnosis.

External education goes on clinical training bases. PDFM is an integrated discipline and includes elements of 23 specialties. Therefore, the main task is to form a correspondence course in practical horizons, exploring all the wide range of nosology necessary for differential diagnosis. The main document of regulating the training of interns, is an individual curriculum. It filled in full-time cycle bases and training of interns conducted independently and controlled by responsible leaders internship teacher in specialized department. In reporting forms that are certified by the signature of the head of the internship and Head Health Region, the number of the treated patients consulted and conducted according to the list manipulation practical skills, the curriculum. In correspondence course teaching interns are required to process the list of mandatory and optional for the study of literature, write a series of essays. This approach provides individualized continuous professional development of theoretical and practical training of young professionals to comply with the demands of modern health care.

Вступ. Термін навчання в інтернатурі за спеціальністю “Загальна практика - сімейна медицина" (ЗПСМ) становить 2 роки, який згідно з типовою та робочою навчальною програмами складається 3 очного навчального процесу на профільній кафедрі та за суміжними спеціальностями, а також заочного стажування на клінічних базах - 21 місяць.

Завданням очної інтернатури $€$ максимальне інформаційне насичення навчання, підвищення якості теоретичної підготовки з ії корекцією на всіх етапах, контроль ефективності практичного та професійного зро-

(ㄱ I. С. Головчак стання, формування навичок клінічного мислення та диференційної діагностики [1,2].

Основна частина. Заочне навчання проходить на клінічних базах стажування. ЗПСМ $є$ інтегрованою дисципліною і включає елементи 23 спеціальностей. Тому основним завданням заочного циклу є формування практичного кругозору, ознайомлення з усім широким спектром нозологій, необхідним для проведення диференційної діагностики. Лікарі-інтерни у своїй роботі повинні керуватися вивченими на очному циклі стандартами та протоколами, в межах яких здійснюється діагностичний, лікувальний та реабілі- 
таційний процес. Вдосконалення техніки виконання практичних навиків і вмінь, робота з режимними регламентуючими наказами, засвоєння технологічних аспектів оформлення та ведення всього розмаїття медичної документації відбувається саме на заочних базах стажування. Враховуючи таку важливість заочної інтернатури, постійно здійснюється пошук нових форм ії оптимальної організації [1].

Основним документом, який регламентує професійну підготовку лікаря-інтерна, $є$ індивідуальний навчальний план. Його заповнення на очному циклі та базах стажування проводиться інтернами самостійно під контролем керівників інтернатури та відповідального викладача профільної кафедри. Такий підхід передбачає індивідуалізацію постійного професійного зростання теоретичної та практичної підготовки молодого фахівця, його відповідність сучасним запитам практичної охорони здоров'я [3].

Навчально-науковим інститутом післядипломної освіти та профільними кафедрами регламентовані усі етапи професійної підготовки інтернів на базах заочного стажування з контролем за її якістю, корекцією та послідовним вдосконаленням. Виконання цих завдань відбувається залежно від стану індивідуальної підготовки кожного молодого лікаря, яку оцінено під час проміжної атестації, результатів вхідного, про-

\section{Списоклітератури}

1. Михайленко I. О. Питання практичної підготовки лікарів-інтернів / І. О. Михайленко // Таврический медикобиологический вестник.-2010.-Т. 13, № 1 (49).-С. 142-143.

2. Пути активизации деятельности врачей-интернов / Н. В. Нагорная, С. С. Острополец, Е. В. Бордюгова [и др.] // Здоровье ребенка. - 2011. - № 3 (30). - С. 72-75.

3. Сапаргалиева А. Д. К вопросу о применении инновационных технологий в подготовке врачей интернов / міжного та заключного контролю рівня знань та вмінь. На заочному циклі інтерни заповнюють звітні форми, які завіряються підписом керівника інтернатури та керівника закладу охорони здоров' я регіону, печаткою установи. У звіті зазначається кількість проконсультованих та пролікованих пацієнтів, проведених маніпуляцій згідно з переліком практичних навиків, передбачених навчальним планом.

На заочному циклі навчання інтерни зобов'язані опрацювати перелік обов'язкової та додаткової для вивчення літератури, вдосконалювати практичні навички, написати низку рефератів. Запропоновані теми реферативних оглядів включають в себе необхідність пошуку наукової інформації шляхом набуття навиків роботи в наукометричних інформаційних системах та базах медичних даних. Це допомагає узагальнювати найсучаснішу інформацію згідно з ключовими словами пошуку [4].

Висновок. Подальші навчально-методичні, педагогічні, наукові розробки профільних кафедр післядипломної освіти повинні бути спрямовані на вдосконалення й уніфікацію всіх розділів роботи з лікарямиінтернами під час очного та заочного циклів навчання. Це дозволятиме досягти оптимальних результатів та сприятиме зростанню ефективності навчального процесу $[2,3]$.

А. Д. Сапаргалиева // Вестник КазНМУ. - http://kaznmu.kz/ press/2012/01/27.

4. Тимофеев А. А. Компьютерные технологии в обучении студента и врача / А. А. Тимофеев. - http://medexpert.org.ua/ modules/myarticles/article_storyid_452.html. 